\title{
„Znaczenie" adaptacji zawodowej w rehabilitacji osób z niepełnosprawnościami
}

\begin{abstract}
STRESZCZENIE
Adaptacja człowieka do środowiska pracy odgrywa ważną rolę w procesie trwania kariery zawodowej i w zasadniczy sposób wpływa na jego rozwój zawodowy. Adaptacja składa się z wielu czynników, które implikują pozytywne lub negatywne stany wykonywania przez człowieka pracy zawodowej.

Artykuł jest teoretycznym zarysowaniem różnych możliwości na przystosowanie człowieka w środowisku pracy zawodowej na gruncie nauk społecznych, takich jak: pedagogika, socjologia, psychologia. Rozwinięciem tematu jest analiza użyteczności wybranych teorii adaptacji zawodowej dla pedagogiki specjalnej w funkcjonowaniu osób z niepełnosprawnościami. Dopełnieniem tej analizy jest wskazanie na różne bariery przystosowania do środowiska pracy niepełnosprawnych. Wnioski obejmują m.in. wzmocnienie aktywizacji zawodowej i aktywizacji socjalnej osób niepełnosprawnych.
\end{abstract}

\section{Słowa kluczowe:}

adaptacja, środowisko, praca, niepełnosprawni, rehabilitacja

\section{ABSTRACT}

Human adaptation to the environment plays an important role in their careers and substantially affects its professional development. Adaptation consists of many factors that imply positive or negative conditions of a person's professional work.

The article is a theoretical outline of various possibilities for adapting people

1 Zbigniew Chodkowski, Wydział Pedagogiczny, Uniwersytet Rzeszowski, Polska, e-mail: zchod@ur.edu.pl. 
in the work environment on the basis of social sciences such as pedagogy, sociology, psychology.

The article is a theoretical outline of various possibilities of adapting a man in the work environment on the basis of social sciences such as pedagogy, sociology, psychology. The development of the topic is the analysis of the usefulness of selected theories of professional adaptation for special pedagogy in the functioning of people with disabilities. Complementing this analysis is pointing to various barriers to adaptation to the working environment of the disabled. Conclusions include, among others, strengthening of professional activation and social activation of people with disabilities.

\section{Keywords:}

adaptation, environment, work, disabled people, rehabilitation

\section{ROZUMIENIE ADAPTACJI W NAUKACH SPOŁECZNYCH}

Życie, tak biologiczne, jak i społeczne, rozwija się poprzez zmiany, co generuje konieczność ciągłego przystosowywania do struktur tworzących się w efekcie tych zmian. To przystosowywanie realizowane jest dzięki mechanizmom adaptacyjnym, stanowiącym podstawowe procesy życiowe, w wymiarze biologicznym jak i społecznym, jednostkowym i grupowym.

Adaptacja, z łac. adaptatio, jest przedmiotem zainteresowań zarówno nauk przyrodniczych, jak i społecznych. W Nowym słowniku pedagogicznym Wincentego Okonia (1998, s. 9) czytamy, że adaptacja to przystosowanie organizmu „w stosunku do zmian zachodzących w środowisku”. Z kolei adaptację społeczną cytowany autor definiuje jako „proces lub wynik procesu uzyskiwania równowagi między potrzebami jednostki a warunkami otoczenia społecznego” (Okoń, 1998, s. 9). W psychologii przyjmowane są różne znaczenia tego pojęcia, w zależności od charakteru środowiska, do którego się ono odnosi. Najogólniej Słownik psychologii Andrew Colmana (2009, s. 4) określa adaptację jako „każdy proces, w którym zachowanie lub doświadczenie podmiotu zmienia się, aby dopasować się do zmian środowiska lub okoliczności, bądź jako reakcja na nacisk społeczny”.

Zróżnicowanie wymiarów adaptacji, znajdujące odzwierciedlenie w zainteresowaniach różnych dyscyplin naukowych, przekłada się na wielość koncepcji adaptacji. Wprawdzie większość z nich uwzględnia złożoność tego procesu i jego mechanizmów, ale jednak różnią się one pod względem akcentowania różnych ich aspektów. Najogólniej koncepcje te można podzielić na biologiczne, psychologiczne, pedagogiczne i socjologiczne. Te ostatnie bywają postrzegane także łącznie, jako ujęcia psychospołeczne bądź społeczno-pedagogiczne. 
Historycznie najwcześniej wyłoniły się koncepcje biologiczne, koncentrujące się na relacjach pomiędzy organizmem a jego otoczeniem, ukierunkowane na przetrwanie jednostkowe i gatunkowe. U źródeł takiego podejścia znajduje się teoria ewolucji Darwina, a jego rozwój wyznaczyły trzy teorie znaczące w naukach biologicznych, tj. teoria homeostazy Waltera Cannona, teoria odruchów Iwana Pawłowa oraz teoria stresu Hansa Selyego. Wszystkie one, najogólniej rzecz ujmując, podejmowały próby przekładania prawidłowości rządzących zachowaniami zwierzęcymi na zachowania wyrażające przystosowanie w świecie ludzi (Popielski, 1986, s. 299-300).

Nauki społeczne znacząco wzbogacają rozumienie przystosowania, uwzględniając celową aktywność człowieka opartą na jego możliwościach poznawczych, przy czym często przystosowanie i adaptacja rozumiane są jako pojęcia synonimiczne. Człowiek, adaptując się do warunków środowiska, przekształca je zgodnie ze swoimi potrzebami i zamierzeniami (Klaus-Stańska, 1994, s. 7). Jednocześnie funkcjonując w świecie kultury, podejmuje realizację określonych ról społecznych, wyznaczonych przyznawaniem odpowiednich uprawnień, ale także i stawianych wymogów. Do tych wymogów trzeba się dostosować, zatem adaptacja stanowi nabywanie umiejętności funkcjonowania w rolach społecznych (Newcomb, 1970, s. 287; Powers, 1971, s. 296). Są to wyzwania najtrudniejsze, bowiem, jak pisze Rene Dubos (1970, s. 288), największym zagrożeniem dla człowieka w jego adaptacji są czynniki środowiska społecznego, w tym zwłaszcza jego powiązania emocjonalne z innymi ludźmi.

Adaptacji rozumianej jako nabywanie umiejętności funkcjonowania w rolach społecznych nie należy utożsamiać z przystosowaniem społecznym. Nabywanie umiejętności pełnienia ról dotyczy przystosowywania się do warunków nie tylko społecznych, ale i fizycznych, w jakich wymogi ról są realizowane, natomiast przystosowanie społeczne odnosi się tylko do przestrzeni kultury. Wyraźnie potwierdzają takie rozróżnienie liczne definicje formułowane na gruncie psychologii i socjologii, a także pedagogiki, chociaż trudno byłoby w tym zakresie doszukiwać się pełnej zgodności pomiędzy propozycjami różnych autorów. I tak np. Andrzej Lewicki (1969, za: Sękowska, 1991, s. 12) przystosowanie społeczne sprowadza do wymiaru aksjonormatywnego, w związku z czym oznacza ono zgodność wartości i norm przestrzeganych przez jednostkę w jej postępowaniu z tymi, które są uznawane za obowiązujące w jej środowisku. Z kolei Mieczysław Michalik (1971, s. 75) w procesie przystosowania społecznego dostrzega przede wszystkim czynne uczestnictwo, twórczą aktywność w działaniu człowieka, przekształcającą środowisko w sposób adekwatny do stosunków społecznych w obiektywnej rzeczywistości danych warunków cywilizacyjnych. Według Elizabeth B. Hurlock 
(1985, s. 498-499) przystosowanie społeczne odnosi się do relacji z innymi ludźmi, zwłaszcza w grupach, z którymi człowiek się identyfikuje. Osoby dobrze przystosowane prezentują postawy prospołeczne, prawidłowo budują interakcje w swoim otoczeniu. Życzliwe i otwarte na innych spotykają się w kręgach swojego uczestnictwa z takimi samymi reakcjami.

W pedagogice, podobnie jak w socjologii, pojęcia przystosowania i adaptacji najczęściej są używane zamiennie, przy czym zakres tych pojęć również mieści się w obszarze stosunków społecznych zespalających grupę. Pedagodzy (Okoń, 2001, s. 12; Nowacki i wsp., 2000, s. 17) odnoszą te pojęcia do procesów uzyskiwania równowagi pomiędzy potrzebami człowieka a warunkami otoczenia społecznego lub do wyniku tych procesów. Te warunki otoczenia społecznego można postrzegać również jako potrzeby osób i grup tworzących otoczenie. W takim znaczeniu A. Jaworowska (1982, s. 102) uzależnia efekt przystosowania społecznego od stopnia, w jakim działanie jednostki w grupie przyczynia się do zaspokojenia potrzeb psychiczno-społecznych zarówno jej samej, jak i innych członków tej grupy.

Utożsamianie pojęć adaptacji społecznej i przystosowania społecznego cechuje propozycje definicyjne także wielu innych autorów, np. K. Olechnickiego i P. Załęckiego (1997, s. 14) czy A. Zycha (2001, s. 17). Jednak nie wszyscy podzielają taki punkt widzenia, zwłaszcza na gruncie psychologii. Według T. Tomaszewskiego (1978, cyt. za: G. Nowak-Starz, 1993, s. 14) przystosowanie społeczne to regulowanie wzajemnych relacji jednostki z jej społecznym otoczeniem dokonujące się poprzez adaptację i działanie. Adaptację wyrażają zmiany, które zachodzą w jednostce, a działanie to przekształcanie otoczenia odpowiednio do tego stanu. Zatem adaptacja stanowiłaby efekt procesów przystosowawczych i jednocześnie mechanizm pobudzający dynamikę tych procesów, ich utrzymywanie się na poziomie optymalnym dla społecznego funkcjonowania jednostki.

W oparciu o porównania różnych koncepcji przyjęto, że dla potrzeb analiz zawartych w tym opracowaniu nie jest ważne szukanie różnic między adaptacją a przystosowaniem. Każde z tych pojęć można postrzegać zarówno w szerokim kontekście ogółu czynników określonego środowiska lub też ograniczać ich zakres do czynników społeczno-kulturowych. W tym drugim przypadku mówimy o adaptacji społecznej bądź społecznym przystosowaniu, nie zapominając o tym, że środowisko społeczne jest integralną częścią środowiska życia, tak w znaczeniu ogólnym, jak i w odniesieniu do środowisk szczegółowych, obejmujących wybrane obszary życiowego funkcjonowania człowieka (rodzinne, szkolne, zawodowe czy lokalne).

Zarówno adaptację, jak i przystosowanie należy postrzegać i jako proces, i jako stan, przy czym proces ma charakter ciągły, natomiast stan jest nietrwały, 
wręcz „chwilowy” ze względu na dynamikę zmian dokonujących się w środowisku. Zmiany generują nowe potrzeby adaptacyjne, stąd ciągłość to cecha istotnościowa procesów przystosowawczych. Jak pisze L. Pytka (2000, s. 224) - przystosowanie jest procesem ciągłego dostosowywania się do wymogów otoczenia, stając się tym samym wynikiem równoważenia procesów akomodacyjno-asymilacyjnych. J. Reykowski (1975, s. 45) wyróżnił adaptację doraźną lub stałą. Doraźna wiąże się z aktualnym doświadczaniem - najczęściej krótkotrwałym - kontaktu z określonym przedmiotem, czynnością lub oddziaływaniem, natomiast stała to utrzymująca się dłuższy czas gotowość do pozytywnego reagowania na ten przedmiot, czynność czy działanie, nie wykluczająca jednak postawy konstruktywnie krytycznej.

Uwzględniając biologiczne koncepcje adaptacji można przyjąć, że proces przystosowania człowieka do otoczenia rozpoczyna się już w życiu płodowym, natomiast proces adaptacji społecznej przynajmniej od momentu przyjścia na świat. To „przynajmniej” odnosi się do teorii neonatologów sugerujących znaczenie pierwszych kontaktów z dzieckiem już w okresie prenatalnym dla jego przystosowania się do środowiska życia poza organizmem matki (Kornas-Biela, 2009, s. 43-88). Najbardziej naturalna adaptacja do życia społecznego w rodzinie rozwija mechanizmy przystosowawcze niezbędne do dobrej jakości społecznego funkcjonowania w środowiskach rówieśniczych przedszkolnych i szkolnych, a następnie w środowisku zawodowym i innych kręgach uczestnictwa człowieka dorosłego. Procesy te mogą przebiegać w różnym tempie i ze zróżnicowanymi efektami, stąd zarówno w naukach przyrodniczych, jak i społecznych bardzo ważne są pytania o wskaźniki diagnozujące efekty adaptacji na danym etapie społecznego funkcjonowania, jak i o czynniki znaczące dla przebiegu i efektów tego procesu. W okresie przed rozpoczęciem aktywności zawodowej poziom przystosowania społecznego może być oceniany na podstawie takich wskaźników, jak: wywiązywanie się z zadań stanowiących wymogi pełnionej roli, zdolność dostosowania się do standardów obowiązujących w grupie, postawy wobec innych uczestników danego obszaru życia społecznego, a także zadowolenie z własnych interakcji i pełnionych przez siebie ról (Hurlock, 1985, s. 499). W okresie szkolnym wyznacznikiem przystosowania jest także motywacja do nauki szkolnej (Paszkowska-Rogacz, 1991, s. 43; Maurer, 1989, s. 192). Wraz z wiekiem zmieniają się kręgi uczestnictwa społecznego, ale podobna pozostaje istota wskaźników procesu adaptacji. Środowisko rodziny generacyjnej zastępuje rodzina prokreacji, środowisko szkolne - środowisko pracy, a dziecięce kręgi rówieśnicze - grupy skupiające dorosłych uczestników życia społecznego, ekonomicznego czy różnych obszarów uczestnictwa w kulturze. Adaptacja do nowych środowisk 
życia przebiega w oparciu o mechanizmy wykształcone i doskonalone w okresach wcześniejszych. Dotyczy to również środowiska pracy.

\section{ADAPTACJA DO ŚRODOWISKA PRACY ZAWODOWEJ JAKO SPECYFICZNY RODZAJ SPOŁECZNEJ ADAPTACJI CZŁOWIEKA}

Adaptacja do środowiska pracy, nazywana też adaptacją zawodową, jest rodzajem adaptacji społecznej, tj. procesem przebiegającym w środowisku pracy od momentu pierwszego zatrudnienia przez cały okres jego trwania. Zmiany miejsca pracy czy rodzaje zatrudnienia rozpoczynają kolejne procesy adaptacyjne, przy czym w dużym stopniu bazują one na doświadczeniach wcześniejszych. Charakter tych doświadczeń może ułatwiać bądź utrudniać przystosowanie do nowych wyzwań zawodowych w kolejnych miejscach pracy czy na nowych stanowiskach. Ponadto zmienność każdego środowiska społecznego, jak również innowacyjność przedsiębiorstw, powodują, że adaptacja trwa przez cały okres zatrudnienia. Jest procesem dwukierunkowym, polegającym, jak pisze S. Kwiatkowski, „,z jednej strony na dostosowywaniu się pracownika do oczekiwań, norm i wymogów zakładów pracy, a z drugiej zaś na uwzględnieniu przez pracodawcę potrzeb i aspiracji osób podejmujących pracę. Jest to więc relacja zwrotna, w której podmiotami są obie zainteresowane strony: pracobiorca i pracodawca.

Funkcjonowanie zawodowe w środowisku pracy obejmuje pewien okres czasu. Rozpoczyna się on przyjmowaniem do pracy, które stanowi pierwszy etap adaptacji. Kolejny etap to wprowadzanie do tego środowiska, a ostatni obejmuje wzajemne przystosowanie. Przyjmowanie do pracy wiąże się z pierwszymi wrażeniami, które mogą mieć wpływ na cały proces adaptacji. Na tym wstępnym etapie następuje pierwszy kontakt z zakładem, przełożonym, z administracją. Może on znacząco wzmacniać pracownika, przełamywać jego onieśmielenie i zagubienie, lęki przed nieznanym. W drugim etapie znaczenie posiada przede wszystkim profesjonalizm wprowadzających do pracy, przydzielonych opiekunów, instruktorów zawodu, przybliżających pracownikowi profil zakładu oraz zapoznających go z zadaniami na obejmowanym stanowisku pracy. Po rozpoczęciu pracy następuje wzajemne przystosowanie poprzez interakcje z pracownikami wcześniej zatrudnionymi, a także przystosowanie do fizycznych warunków pracy i zadań przypisanych podjętej roli zawodowej (Kwiatkowski, 1995, s. 219).

Adaptacja zawodowa dotyczy pracowników podejmujących swoje pierwsze zatrudnienie, jak i zmieniających miejsce czy stanowisko pracy. Jest procesem ciągłym, jednak najmocniej jej efekty uwidaczniają się we wstępnym okresie 
zatrudnienia. Te efekty mogą być rozpatrywane z perspektywy przedsiębiorstwa, jak i nowozatrudnionego pracownika. Najbardziej wymierne efekty dla przedsiębiorstwa to ekonomiczny zysk, ale nie mniej ważne jest także to, co pracownik wnosi w atmosferę środowiska, jego wpływ na kulturę pracy, jej etos. Natomiast efekty adaptacji dla pracownika to jego przystosowanie do różnych elementów środowiska pracy. S. Kwiatkowski (1995, s. 219-220) wyróżnia wśród nich:

a) czynniki fizyczne, takie jak: temperatura, ciśnienie, oświetlenie, promieniowanie, hałas;

b) techniczne wymogi pracy, w tym maszyny, narzędzia organizacje pracy i normy technologiczne;

c) warunki społeczne, w tym relacje międzyludzkie formalne i nieformalne, zależności, wartości i normy.

Istnieje wiele czynników ułatwiających bądź utrudniających adaptację do środowiska pracy. Należą do nich zarówno czynniki natury fizycznej, jak i psychospołecznej. Większe szanse adaptacji istnieją w warunkach fizycznych mniej uciążliwych, nie powodujących przykrych objawów somatycznych, takich jak: ból głowy, poczucie przemęczenia, alergie. Łatwiej jest także przystosować się do środowiska pracy, w którym dominuje współdziałanie, a nie konflikty. Łatwiej jest wówczas, gdy środowisko pracy odpowiada celom wyrażającym życiowe aspiracje pracownika, kiedy posiada on poczucie zadowolenia i przejawia pozytywne postawy wobec tego, co i gdzie robi, realizując podjętą rolę zawodowa oraz czuje się pozytywnie zmotywowany do doskonalenia swojego funkcjonowania w tej roli.

Jeszcze inne spojrzenie na proces adaptacji zawodowej proponuje J. Karney (2007, s. 154). Według tej autorki przystosowanie zawodowe to adekwatność potencjału pracownika do środowiska i sytuacji pracy, którą można osiągać przez adaptację pracownika do pracy lub poprzez dostosowywanie warunków pracy do potrzeb pracownika. Zatem przystosowanie zawodowe byłoby pojęciem szerszym, w którym adaptacja to tylko część mechanizmów uzyskiwania harmonijnej równowagi między wymogami środowiska pracy a możliwościami i oczekiwaniami pracownika. Do takiej równowagi dąży sam pracownik, dla którego oznacza ona dobrą jakość zawodowego funkcjonowania nagradzaną poprzez gratyfikacje zewnętrzne (wynagrodzenie, prestiż), jak i wewnętrzne (przejawiające się poczuciem satysfakcji zawodowej). Przystosowanie pracownika jest także istotne dla osiągania celów pracodawcy, przekłada się na efekty jego zawodowego funkcjonowania, a tym samym na osiągane zyski przedsiębiorstwa.

Aktywna adaptacja według W. Szewczuka (1998, za: Dykcik, 2010, s. 290) jest to działalność człowieka różnego rodzaju, np. poznawcza, organizacyjna, motywacyjna, wychowawcza, artystyczna, usługowa czy sportowa, w tym także 
i zawodowa. Przebiega w oparciu o mechanizmy adaptacyjne człowieka potwierdzające jego zdolność do zaspokajania potrzeb w zmieniających się środowiskach. Psychiczne bariery adaptacji, tkwiące w jednostce dążącej do adaptacji, przejawiają się zaburzeniami równowagi psychicznej, zwłaszcza w sytuacjach trudnych.

\section{UŻYTECZNOŚĆ TEORII ADAPTACJI ZAWODOWEJ DLA PEDAGOGIKI SPECJALNEJ}

Adaptacja zawodowa jest procesem zbliżającym elementy, do których się odnosi. Łączy pracownika w jego roli z innymi aktorami ról zawodowych, co przejawia się jakością komunikacji, współdziałania, współpracy, ale także łączy pracownika z miejscem pracy, jego lokalizacją, wyposażeniem, celami organizacji, co z kolei przekłada się na postawę współodpowiedzialności za całość środowiska pracy. W tym znaczeniu adaptacja zbliża się do pojęcia integracji. Andrzej Radziewicz-Winnicki (2008, s. 460-461) pisze, przywołując konstatacje Bebout`a, Bredemeiera (1963), że są to do pewnego stopnia te same pojęcia, różniące się przyjmowanymi punktami widzenia. Adaptacja wyraża perspektywę jednostki bądź zespołu, natomiast integracja - perspektywę całego systemu, którego ta jednostka jest częścią. Integracja danego systemu to oczekiwane następstwo adaptacji współtworzących go jednostek. Obydwa te procesy stanowią mechanizmy tworzenia się grup społecznych. Zatem w odniesieniu do środowiska zawodowego należy przyjąć, że przebieg adaptacji oznacza tworzenie się więzi pomiędzy pracownikami, czyli decyduje o tym, że ze zbioru jednostek zlokalizowanych w tej samej przestrzeni ze względu na podjęte role zawodowe stają się oni grupą społeczną zdolną do wspólnego działania: ukierunkowanego na określone cele danej organizacji, takie jak: produkcja, optymalizowanie jej warunków, maksymalizowanie zysków, minimalizowanie strat. Adaptacja w swej integracyjnej funkcji utrzymuje dynamikę systemu, przeciwdziała jego destabilizacji i dezintegracji, ułatwia funkcjonowanie całej struktury Takie zależności powodują, że adaptacja w środowisku zawodowym to nie tylko interes pracownika, jego samopoczucia, satysfakcji zawodowej i zdrowia psychicznego, ale również interes organizacji, jej zysków ekonomicznych i wizerunkowych. Znajduje to w praktyce przełożenie na działania integracyjne firm i korporacji. Towarzyskie spotkania czy wspólne wyjazdy mają, z założenia, przyspieszać procesy adaptacyjno-integracyjne przez budowanie więzi nieformalnych i zespalanie ich z więzią formalną. Te integracyjne działania korporacji czy firm nabierają nowego znaczenia w sytuacji, kiedy w ich strukturę społeczną zdominowaną pod względem liczebności przez pełnosprawnych 
włączane są osoby z niepełnosprawnościami. Z punktu widzenia teorii integracji można wówczas mówić o integracji zawodowej „specjalnej”, czyli takiej, w której potencjalne efekty tego procesu wymagają dodatkowego wsparcia, np. poprzez zmniejszenie czasu zatrudnienia, zredukowanie części obowiązków, przydzielenie opiekuna, zorganizowanie dostępu do rehabilitacji fizycznej, dostosowanie miejsca i narzędzi pracy. Takie działania, adekwatne do potrzeb osoby z niepełnosprawnością w konkretnych warunkach środowiska zawodowego, najogólniej można określić normalizacją zawodową.

Normalizacja w pedagogice specjalnej ,jest podstawowym paradygmatem celów działań rehabilitacyjnych podejmowanych jako społecznie ważny problem i zadanie tworzenia realnych warunków bytu umożliwiających typowe, normalne zachowania i pozytywne doświadczenia” (Dykcik, 2005, s. 151).

Normalizację należy też postrzegać jako zjawisko z zakresu świadomości społecznej. W tym znaczeniu Cz. Kosakowski pisze, że normalizacja życia społecznego niezbędna dla integracji osób niepełnosprawnych wyraża się odchodzeniem od marginalizowania problemów tych osób, spychania ich na peryferie życia (1998, s. 226). Normalizacji nie jest skierowana na osiąganie przez ogół osób z niepełnosprawnościami jakiejś przeciętnej normy umiejętności czy zachowania, bo to w wielu sytuacjach nie byłoby możliwe, ale na częściowe przynajmniej wyrównywanie ich szans i tworzenie perspektyw życiowych w zakresie standardów bytowych, edukacyjnych i zawodowych.

Niepełnosprawni żyją w świecie zbudowanym przez pełnosprawnych, stąd muszą pokonywać wiele barier fizycznych i społecznych w różnych środowiskach swojego funkcjonowania, także w środowisku zawodowym (Nowak, 2005, s. 395). Ta dominacja wynika zarówno z ograniczonych możliwości samych osób z niepełnosprawnościami, jak też i z postaw pełnosprawnych: marginalizujących, odmawiających praw do autonomii oraz współdecydowania o warunkach wspólnej przestrzeni życiowej. Te wielowiekowe dyskryminacje spowodowały brak uwzględniania potrzeb osób z różnymi niepełnosprawnościami w zakresie infrastruktury, rozwiązań prawnych, administracyjno-organizacyjnych, a także ukształtowały dyskwalifikujące postawy, oparte na stereotypach i uprzedzeniach. Wszystko to sprawia, że współcześnie konieczne jest kompensowanie tych zaniedbań wyrównujące szanse adaptacji życiowej osób z różnymi niepełnosprawnościami. Dotyczy to także szans adaptacji zawodowej przez normalizację środowiska pracy.

Jak pisze W. Dykcik (2010, s. 294), w procesie normalizacji osób z niepełnosprawnościami problemy pomocy w adaptacji zawodowej należą do kwestii priorytetowych. Pomoc ta wyraża się jeszcze przed podjęciem aktywności 
zawodowej, przez edukację zawodową i poradnictwo, chodzi o wyposażenie w kompetencje ogólne i zawodowe, ale także o rozpoznanie „indywidualnych predyspozycji, istotnych w rozwoju zawodowym, sukcesie w zatrudnieniu i pracy zarobkowej”.

Integralna złożoność struktur człowieka, także z niepełnosprawnością, powoduje, że zarówno procesy intergacyjno-normalizacyjne, jak i rehabilitacyjno-terapeutyczne ukierunkowane są na cel nadrzędny, jakim jest uzyskiwanie autonomii w stopniu optymalnie możliwym dla danej osoby. Także w procesie adaptacji zawodowej jednym z celów nadrzędnych jest autonomia, tak dla danej jednostki uzyskującej poprzez pracę zaspokajanie ważnych potrzeb społecznych, jak i dla organizacji zwiększającej efektywność pracy poprzez działania normalizacyjne.

Teorie adaptacji współtworzą koncepcję spójną, wieloaspektową, pozwalającą na interpretacje interdyscyplinarne, holistyczne, a tym samym umożliwiające większą skuteczność wdrażania programów wspierających osoby z niepełnosprawnościami. Pozwalają dostrzegać ciągłość procesów związanych z zawodowym funkcjonowaniem tych osób, już od okresów rozwijających mechanizmy adaptacyjne w okresie edukacji ogólnej i zawodowej, poprzez przystosowywanie się do środowiska pracy w różnych okresach realizacji kariery zawodowej oraz w różnych wymiarach tego środowiska: fizycznym, organizacyjnym, psychospołecznym, a także aksjologicznym.

Teorie adaptacji łączą się i wzbogacają teorie ważne dla pedagogiki specjalnej, w tym zwłaszcza teorie odnoszące się do społecznego funkcjonowania, również funkcjonowania w środowisku pracy, w tym zwłaszcza teorie integracji, normalizacji i autonomii, tworzenia optymalnych standardów jakości życia

\section{REHABILITACJA JAKO FORMA ADAPTACJI DO ŚRODOWISKA PRACY W FUNKCJONOWANIU ZAWODOWYM OSÓB Z NIEPEŁNOSPRAWNOŚCIAMI}

Adaptacja do środowiska pracy rozpoczyna się w momencie nawiązania stosunku pracy, ale przygotowanie do niej obejmuje znacznie wcześniejsze okresy, tj. okres edukacji zawodowej, a nawet edukacji ogólnej, kiedy to z jednej strony kształtują się aspiracje i oczekiwania zawodowe, a z drugiej rozwijają się kompetencje psychiczne ważne dla radzenia sobie w przyszłym funkcjonowaniu zawodowym. Są to procesy trudne dla każdego młodego człowieka, a osoba z niepełnosprawnością ma dodatkowo utrudnioną adaptację do warunków pracy i życia.

Tadeusz Majewski (1995, s. 40) opisuje rehabilitację osoby z niepełnosprawnością jako niezbędny proces, dzięki któremu może dojść do zminimalizowania 
niepełnosprawności i przygotowania tej osoby do życia, a także do wykonywania pracy zawodowej. W procesie tym, według Światowej Organizacji Zdrowia, stosuje się kompleksowe środki medyczne, pedagogiczne, społeczne i zawodowe w celu usprawnienia osoby z naruszoną sprawnością organizmu do możliwie najwyższego poziomu.

W zależności od problemów i środków Majewski wyróżnia rehabilitację:

- leczniczą (medyczną), polegającą na stosowaniu metod i środków leczniczych w celu zmniejszenia lub złagodzenia skutków chorób lub urazów oraz skorygowaniu wad wrodzonych;

- psychologiczną, która jest procesem wewnętrznych przemian dokonujących się w osobie niepełnosprawnej, polegających na adaptacji psychicznej do sytuacji i warunków zaistniałych na skutek niepełnosprawności;

- zawodową, polegającą na przygotowaniu osoby z niepełnosprawnością do pracy oraz zapewnienie jej pracy zgodnie z psychofizycznymi możliwościami oraz kwalifikacjami zawodowymi;

- społeczną, która ma na celu integrację lub reintegrację osoby z niepełnosprawnością we wszystkie przejawy życia społecznego, usuwając jednocześnie ekonomiczne i społeczne bariery (Majewski 1995, s. 41-49).

Ujmując ogólnie, rehabilitacja polega na zminimalizowaniu problemów wynikających z niepełnosprawności. Ostatecznym jej celem ma być społeczna i zawodowa integracja lub reintegracja osoby z niepełnosprawnością (Majewski 1995, s. 41-42).

\section{BARIERY PRZYSTOSOWANIA DO ŚRODOWISKA PRACY, ZE SZCZEGÓLNYM UWZGLĘDNIENIEM PROBLEMÓW OSÓB Z NIEPEŁNOSPRAWNOŚCIAMI}

Przystosowanie do środowiska pracy jest procesem bardzo złożonym ze względu na różne wymiary tego środowiska, mogące generować równocześnie wiele barier. Czajka i Tulski (1984, s. 50-52) wymieniają następujące płaszczyzny adaptacji człowieka do sytuacji pracy:

a) aktywne dostosowywanie się do środowiska społecznego pracy w zakresie:

- przestrzegania norm i zachowań wypracowanych przez określony zespół;

- wnoszenie do zespołu nowych wartości społecznie akceptowalnych, takich jak: solidność, rzetelność, odpowiedzialność, pracowitość;

b) aktywne przystosowywanie się do wykonywania obowiązków pracy zawodowej: 
- dążenie do opanowania umiejętności zawodowych (jakość i ilość wykonywanych zadań, dbałość o sprzęt i narzędzia pracy, przestrzeganie zasad procesów produkcyjnych);

- osiąganie mistrzostwa w zawodzie;

c) aktywne przystosowywanie do fizycznego środowiska pracy jako całokształtu bodźców fizycznych, chemicznych, biologicznych oddziałujących na ustrój fizjologiczny i psychologiczny człowieka;

d) aktywne przystosowywanie się do zadań organizacji (demokratyzacja życia społeczności zakładowej, współudział w podejmowaniu decyzji, współodpowiedzialność za realizację zadań itp.);

e) aktywne przystosowywanie się do formalnej organizacji zakładu pracy, czyli do układu oficjalnych stosunków określonych przepisami, regulaminami i statutami.

Jak wynika z powyższej klasyfikacji, czynniki adaptacji w środowisku pracy są zróżnicowane, część z nich odnosi się wyłącznie do niektórych sytuacji zawodowych, jak np.: określone umiejętności, zdolności przywódcze, umiejętności kierowania grupą. Są wśród nich również takie, które wyrażają przystosowanie zawodowe w każdym środowisku pracy, niezależnie od charakteru tego środowiska i pełnionej w nim roli zawodowej. Należą do nich: aspiracje zawodowe, motywacja, postawy zawodowe oraz satysfakcja zawodowa, czyli zadowolenie z własnego funkcjonowania w środowisku pracy. Nie są to z pewnością jedyne ważne czynniki adaptacji w środowisku pracy, jednak do dalszej uszczegółowionej analizy zostały wybrane nie tylko ze względu na znaczenie dla przebiegu i efektów adaptacji zawodowej, ale również z powodu ich uniwersalności. Niezależnie od charakteru realizowanej roli zrównoważone aspiracje, pozytywne motywacje i postawy zawodowe oraz odczuwana satysfakcja aktywizują do większego zaangażowania w zadania wynikające z wymogów przypisanych do tej roli.

Bariery adaptacji zawodowej wiążą się z funkcjonowaniem zawodowym osób z niepełnosprawnościami. Są to:

1. Postawy dyskwalifikujące potrzeby i możliwości zawodowe osób z niepełnosprawnościami. Ich znaczenie ujawnia się jeszcze przed podjęciem zatrudnienia w postaci odczuwania niechęci pełnosprawnych, ich niezrozumienia i braku chęci do współdziałania na płaszczyźnie zawodowej. Jak podkreślają pedagodzy specjalni, część społeczeństwa ocenia krytycznie przygotowanie zawodowe osób z niepełnosprawnościami, uważa je za niepotrzebne, mało skuteczne przy niewielkich szansach zatrudnienia, a jednocześnie bardzo kosztowne (Smith 2008, s. 61-62; Dykcik 2010, s. 291). 


\section{Bariery:}

Jedną z głównych barier ograniczających możliwości zawodowego funkcjonowania osób z niepełnosprawnościami jest niechęć pracodawców do zatrudniania takich osób, oparta na przekonaniu o ich niskiej wydajności, wysokiej absencji, nadmiernych przywilejach, postaw roszczeniowych, dużych kosztach zatrudnienia (Dykcik, 2010, s. 296). Pracodawcy boją się odpowiedzialności za bezpieczeństwo tych osób, ale także za gorszą jakość ich pracy, nieterminowość (Dykcik, 2010, s. 296).

Jak podaje J. Czapiński (2009, s. 333), istnieją bardzo duże dysproporcje pomiędzy wskaźnikami bezrobocia osób z niepełnosprawnościami a pełnosprawnych, tzn. niepełnosprawni mają problemy ze znalezieniem zatrudnienia niemal trzykrotnie częściej niż pełnosprawni. Te proporcje w różnych okresach ulegają zmianom, jednak ciągle niepełnosprawność to jedna z głównych barier uczestnictwa człowieka w życiu zawodowym, przy czym bariery te to nie tylko ograniczenia danej jednostki utrudniające wykonywanie niektórych obowiązków zawodowych, ale również postawy w środowisku pracy przejawiające się brakiem przystosowania tak środowiska fizycznego, jak i społecznego do rodzaju i stopnia niepełnosprawności danego pracownika (Dykcik 2010, s. 292). W Polsce uruchomione zostały mechanizmy wspierające aktywizację i aktywność zawodową osób z niepełnosprawnościami, które mają na celu, między innymi, eliminowanie obaw pracodawców przed ponoszonymi kosztami takiej polityki zatrudnienia. Są to: między innymi dofinansowywanie, specjalnego wyposażenia miejsc pracy, dopłaty do wynagrodzeń, pomoc w organizowaniu i funkcjonowaniu zakładów pracy chronionej, możliwość zatrudniania asystenta osoby z niepełnosprawnością (Grzonka, 2010, s. 50-65, Dykcik, 2010, s. 299). Poza wzmocnieniami potencjalni pracodawcy osób z niepełnosprawnościami są motywowani również karami. Ustawa zobowiązuje pracodawców do zatrudniania określonej liczby niepełnosprawnych w stosunku do ogólnego stanu zatrudnienia - brak dostosowania się do tego wymogu skutkuje nakazem odpowiednich wpłat na fundusz rehabilitacyjny (Dykcik, 2010, s. 301). Takie rozwiązania są korzystne, ale nie wystarczające z dwóch przynajmniej powodów:

1.1.1. Po pierwsze, motywowanie pracodawców wyłącznie wymogami formalnymi zachęca ich do szukania sposobów „obchodzenia” kłopotliwych zapisów ustawowych i rozporządzeń.

1.1.2. Po drugie, osoba z niepełnosprawnością potrzebuje nie tylko oferty zatrudnienia, ale przede wszystkim warunków do adaptacji w środowisku pracy, bo tylko wówczas zatrudnienie wypełni funkcje rewalidacyjne. Warunki te to często odpowiednie do jej ograniczeń rozwiązania techniczne w miejscu pracy i w tym zakresie pracodawca może uzyskiwać 
odpowiednie rekompensaty finansowe. Jednak zawsze konieczne dla pomyślnego przebiegu adaptacji są czynniki psychospołeczne środowiska pracy, w tym postawy akceptacji inności osoby z niepełnosprawnością i gotowości integracyjnej we współdziałaniu z taka osobą. Tych warunków nie da się zrekompensować finansowo, stąd dla adaptacji osób z niepełnosprawnościami w środowiskach zawodowych kluczowe znaczenie ma kształtowanie postaw prointegracyjnych, w tym upowszechnianie wizerunku osoby z niepełnosprawnością jako zdolnej do funkcjonowania zawodowego, potrzebującej pracy jak każdy inny człowiek i przygotowanej do radzenia sobie z obowiązkami zawodowymi.

1.1.3. I po trzecie, każda adaptacja, także zawodowa, jest procesem dwustronnym, zatem przygotowanie do funkcjonowania zawodowego warunkujące pomyślny przebieg procesów adaptacyjnych to także przygotowanie osób z niepełnosprawnościami. Przede wszystkim wyposażenie ich w wiedzę i umiejętności oraz umiejętności poszkolnego samokształcenia, ale także i rozwijanie ich kompetencji społecznych. Osoby z niepełnosprawnościami są pod tym względem różne, podobnie jak pełnosprawni. Ich ograniczenia częściowo przynajmniej mogą kompensować zabiegi rehabilitacyjne, natomiast ważne jest, by w procesie socjalizacji, poczynając już od socjalizacji pierwotnej, kształtowały się u nich kompetencje prospołeczne, takie jak: gotowość do współdziałania, poczucie odpowiedzialności za siebie i swoje środowisko czy zdolność do samooceny zarówno posiadanych ograniczeń, jak i możliwości. Zatem przygotowanie do adaptacji zawodowej musi się rozpoczynać bardzo wcześnie i powinno obejmować zarówno kręgi osób pełnosprawnych, jak i z różnymi ograniczeniami sprawności.

Rafał Dziurla proponuje wprowadzenie terminu zatrudnienie wspomagane, które wprowadzono w Stanach Zjednoczonych w latach osiemdziesiątych ubiegłego wieku. Zatrudnienie wspomagane ma na celu wspieranie osób z niepełnosprawnościami poszukującymi pracy (w różnych środowiskach) poprzez nawiązanie z nimi czasowej relacji, w efekcie której osoba poszukująca pracy uzyskuje pewną samodzielność w wykonywaniu swoich obowiązków pracownika. Celem zatrudnienia wspomaganego jest płatna praca na otwartym rynku pracy. Jest ona wspierana przez odpowiednie działania jak np.: nadzór, szkolenie i transport. Zatrudnienie wspomagane wpływa na minimalizację barier w zakresie przystosowania się pracownika z niepełnosprawnością do wykonywania pracy (Dziurla, 2017, s. 107).

Wzmocnieniem minimalizacji barier dla osób z niepełnosprawnościami jest program „Dostępność Plus”, który wystartował 23 kwietnia 2018 r. W ramach tego 
programu przestrzeń publiczna ma być w pełni dostosowana do potrzeb wszystkich obywateli doświadczających trwałych lub czasowych ograniczeń w mobilności czy percepcji, w szczególności osób z niepełnosprawnościami i osób starszych. Służyć temu ma poprawa dostępności infrastruktury publicznej, produktów i usług w ośmiu obszarach: architektura, transport, edukacja, służba zdrowia, cyfryzacja, usługi, konkurencyjność przedsiębiorstw i koordynacja (Nobis, bd.).

\section{ZAKOŃCZENIE}

W Polsce rozwiązywanie problemów aktywizacji zawodowej osób z niepełnosprawnościami rozpoczyna się dopiero po 1989 roku. Po dokonaniu się transformacji ustrojowo-ekonomicznej sytuacja zaczyna się radykalnie zmieniać. Do najważniejszych zmian należy zaliczyć:

1. Zmiany postaw samych osób z niepełnosprawnościami, coraz lepiej zrehabilitowanych i wykształconych, posiadających rosnącą świadomość własnej wartości i szans na dobrą jakość życia.

2. Upowszechnianie się wśród pełnosprawnych świadomości, że duże grupy społeczeństwa, które chciałyby i mogłyby pracować, są tej pracy pozbawione tylko dlatego, że gorzej widzą, gorzej słyszą, wolniej myślą czy mają większe trudności w poruszaniu się.

3. Otwarcie się Polski na doświadczenia aktywizacji zawodowej w krajach Europy Zachodniej, przekonujące, że inwestycje w pracę niepełnosprawnych mogą być dla społeczeństwa opłacalne.

4. Konieczność dostosowania się do wymogów Unii Europejskiej w zakresie obowiązujących ustaw i rozporządzeń oraz konkretnych rozwiązań instytucjonalnych.

5. Większe możliwości finansowego wspierania aktywizacji i aktywności osób z niepełnosprawnościami wynikające z wymogów prawno-administracyjnych oraz dostępności funduszy unijnych.

Po roku 1989 konkurencyjność rynku pracy sprawiła, że niepełnosprawni znaleźli się w bardzo trudnej sytuacji jako słabsi i skazani na przegraną w konkurencji ze zdrowymi, tym bardziej że często stawali oni do tej konkurencji także z gorszym wykształceniem i niższymi kwalifikacjami. Jak pisze R. Ossowski (1999, s. 321), częstymi przejawami ich dyskryminacji było zatrudnianie w niepełnym wymiarze godzin, segregowanie, odtrącanie.

Ustawa z 1991 roku o zatrudnieniu i rehabilitacji osób niepełnosprawnych nakłada na pracodawców obowiązek zatrudniania osób z niepełnosprawnościami 
w wymiarze co najmniej 6\% ogólnego zatrudnienia z zapewnieniem im określonego uprzywilejowania w zakresie czasu pracy wysokości płac i szczególnej ochrony pracy. Brak dostosowania się do wymogów ustawowych może skutkować karami finansowymi - wpłaty na PFRON. Jak zauważa J. Jończyk (1996, s. 40): „ideą jest równość szans osób z niepełnosprawnościami, środkiem jest polityka zatrudnienia i ustawa jako jej instrument, a celem - rehabilitacja zawodowa i społeczna osób niepełnosprawnych”.

Dla przykładu, Państwowy Fundusz Rehabilitacji Osób Niepełnosprawnych opracował program „Stabilne zatrudnienie - osoby niepełnosprawne w administracji i służbie publicznej”, który wszedł w życie 17 lipca 2017 roku. Celem programu jest podniesienie wskaźnika zatrudnienia osób niepełnosprawnych w administracji publicznej. Realizacja programu została zaplanowana na 4 lata. Przyjęto założenie, że będzie zatrudnionych co najmniej 2500 osób niepełnosprawnych na okres nie krótszy niż 12 miesięcy².

Agnieszka Lipińska-Grobelny i Mariola Wolan-Nowakowska (2017, s. 59-60) koncentrują się na korzyściach ekonomicznych dla przedsiębiorców związanych z zatrudnieniem osób z niepełnosprawnościami w związku z systemem kwotowym. System ten daje możliwość ograniczenia kosztów przedsiębiorstwa, które wynikają z obowiązkowych wpłat na PFRON. Analiza kosztów związanych z niezatrudnianiem oraz kosztów i zysków związanych z zatrudnieniem osób z niepełnosprawnościami powinna być punktem wyjścia tworzenia polityki zarządzania niepełnosprawnością w przedsiębiorstwie.

We współczesnych społeczeństwach podejmowane są wielorakie próby wyrównywania szans aktywności zawodowej osób z różnymi niepełnosprawnościami. Międzynarodowa Organizacja Pracy przyjmuje, że osoba z niepełnosprawnością to taka, „której szanse uzyskania, utrzymania i awansu we właściwym zatrudnieniu są poważnie ograniczone na skutek fizycznej lub psychicznej niepełnosprawności oficjalnie orzeczonej” (Majewski, 2001, s. 395) (za: Nowak, 2005, s. 394). Podobna definicja jest przyjmowana w polskiej Ustawie o rehabilitacji zawodowej i społecznej osób niepełnosprawnych z 27 sierpnia 1997 roku. Zapis ustawy rozróżnia ograniczenia fizyczne, psychiczne i umysłowe ograniczające, utrudniające lub uniemożliwiające funkcjonowanie w rolach zawodowych trwale lub okresowo (Dz. U. z 1997 roku, nr 123, poz. 776).

Wszelkie procedury związane z zatrudnianiem osób z niepełnoprawnościami powinny być integralnym elementem polityki zarządzania zasobami ludzkimi

2 https://www.pfron.org.pl/o-funduszu/programy-i-zadania-pfron/programy-i-zadania-real/ program-stabilne-zatrud/tresc-programu/ [dostęp: 28 lutego 2019 r.]. 
w miejscu pracy. Wdrażanie przez pracodawcę polityki zatrudniania osób z niepełnosprawnościami wiąże się z inwestowaniem w kapitał ludzki. Z jednej strony pracodawca ma szansę pozyskać kompetentnego, zaangażowanego oraz odpowiedzialnego pracownika. Z drugiej strony praca dla osób z niepełnosprawnościami daje im szansę na rozwój własnych możliwości, na budowanie własnej tożsamości oraz obrazu siebie w kategoriach sprawności i skuteczności zawodowej (Lipińska-Grobelny, Wolan-Nowakowska, 2017, s. 59-60).

\section{Bibliografia}

Colman, A.M. (2009). Słownik psychologii. Tłum. A. Cichowicz, M. Guzowska-Dąbrowska, P. Nowak, H. Turczyn-Zalewska. Warszawa: Wydawnictwo Naukowe PWN.

Czajka, S. Tulski, J. (1987). Praca i adaptacja. Warszawa: Wydawnictwo Szkolne i Pedagogiczne.

Czapiński, J. (2009). Niepełnosprawność. W: J. Czapiński, T. Panek (red.), Diagnoza społeczna. Warszawa: RMS. Departament ds. Programów. Pobrane z: https://www. pfron.org.pl/o-funduszu/programy-i-zadania-pfron/programy-i-zadania-real/program-stabilne-zatrud/tresc-programu/.

Dubos, R. (1970). Człowiek, środowisko, adaptacja. Tłum. S. Bogusławski, A. Czerwiński. Warszawa: PZWL.

Dykcik, W. (2005). Pedagogika specjalna wobec aktualnych sytuacji i problemów osób niepełnosprawnych. Poznań: Wydawnictwo Naukowe Polskiego Towarzystwa Pedagogicznego, Oddział w Poznaniu.

Dykcik, W. (2010). Tendencje rozwoju pedagogiki specjalnej. Osiągnięcia naukowe i praktyka, Poznań: Wydawnictwo Naukowe Polskiego Towarzystwa Pedagogicznego, Oddział w Poznaniu.

Dziurla, R. (2011). Zatrudnienie wspomagane dla osób niedosłyszących, niesłyszących i ich otoczenia społecznego realizowane w polskiej Fundacji pomocy Dzieciom Niedosłyszącym ECHO w Warszawie. W: K. Boguszewska i in. (red.), Zatrudnienie wspomagane: materiały konferencyjne (s. 105-114). Warszawa: Ministerstwo Pracy i Polityki Społecznej: Biuro Pełnomocnika Rządu do Spraw Osób Niepełnosprawnych.

Grzonka, L. (2010). Zatrudnianie osób niepetnosprawnych. Warszawa: Wydawnictwo C.H. Beck.

Hurlock, E.B. (1985). Rozwój dziecka. Tłum. M. Tyszkowa. Warszawa: Wydawnictwo Naukowe PWN.

Jaworowska, A. (1982). Rodzina a przystosowanie społeczne dziecka W: L. Wołoszynowa (red.), Materiały do nauczania psychologii, seria 2, t. 9. Warszawa: Wydawnictwo PWN. Jończyk, J. (1996). Prawne regulacje rehabilitacji leczniczej i zawodowej. W: J. Mikulski, J. Auleytner (red.), Polityka społeczna wobec osób niepełnosprawnych. Drogi do integracji (s. 34-41). Warszawa: Wydawnictwo WSP TWP.

Karney, J.E. (2007). Psychopedagogika pracy. Warszawa: Wydawnictwo Akademickie Żak. Klaus-Stańska, D. (1994). Między wzruszeniem a śmiechem. Kraków: Wydawnictwo Impuls. 
Kornas-Biela, D. (2009). Pedagogika prenatalna - nowy obszar nauk o wychowaniu. Lublin: Wydawnictwo KUL.

Kosakowski, Cz. (1998). Transformacja ustrojowa szansą czy tez zagrożeniem dla rodzin wychowujących dzieci niepełnosprawne. W: H. Górecka (red.), Bezpieczeństwo rodziny w okresie transformacji ustrojowej (s. 221-230). Olsztyn: Decora.

Kwiatkowski, S.M. (1995). Zakład pracy jako środowisko wychowawcze. W: T. Pilch, I. Lepalczyk (red.), Pedagogika społeczna (s. 214-221). Warszawa: Wydawnitwo Akadem. Żak.

Lewicki, A. (1969). Co to jest psychologia kliniczna? W: A. Lewicki (red.), Psychologia kliniczna. Warszawa: Wydawnictwo Naukowe PWN.

Lipińska-Grobelny, A., Wolan-Nowakowska, M. (2017). Zarządzanie różnorodnością w miejscu pracy a niepełnosprawność. W: M. Wolan-Nowakowska, B. Trochimiak (red.), Zatrudnienie wspomagane szansq na samodzielność osób z niepełnosprawnościami (s. 51-62). Warszawa: Wydawnictwo Akademii Pedagogiki Specjalnej.

Majewski, T. (1995). Rehabilitacja zawodowa osób niepełnosprawnych. Warszawa: Centrum Badawczo-Rozwojowe Rehabilitacji Osób Niepełnosprawnych.

Majewski, T. (2009). Problemy rehabilitacji zawodowej i społecznej osób niepełnosprawnych. W: W. Dykcik (red.), Pedagogika specjalna (s. 395-408). Poznań: Wydawnictwo UAM. Michalik, M. (1971). Armia zawód moralność. Warszawa: Wydawnnictwo MON. Nobis, E. Start programu Dostępność Plus. Pobrane z: https://www.pfron.org.pl/aktualnosci/ szczegoly-aktualnosci/news/start-programu-dostepnosc-plus/.

Nowak, P. (2005). Praca zawodowa osób niepełnosprawnych. W: T. Żółkowska (red.), Pedagogika specjalna - aktualne osiqgniecia i wyzwania (s. 395-400). Szczecin: Wydawnictwo Inplus Oficyna.

Okoń, W. (1989). Nowy słownik pedagogiczny. Warszawa: Wydawnictwo Akademickie Żak. Olechnicki, K., Załęcki, I.P. (1997). Słownik socjologiczny. Toruń: Graffiti BC.

Ossowski, R. (1999). Teoretyczne i praktyczne podstaw rehabilitacji. Bydgoszcz: Wydawnictwo Uczelniane WSP w Bydgoszczy.

Ossowski, R. (1996). Zagrożenia dla osób niepełnosprawnych w procesie adaptacji psychicznej. W: J. Mikulski, J. Auleytner (red.), Polityka społeczna wobec osób niepełnosprawnych. Drogi do integracji (s. 42-54). Warszawa: Wyd. WSP TWP.

Popielski, K. (1987). Człowiek - Pytanie Otwarte. Studia z logoteorii i logoterapii. Lublin: Wydawnictwo KUL. Pytka, L. (2000). Pedagogika resocjalizacyjna. Wybrane zagadnienia teoretyczne, diagnostyczne i metodyczne. Warszawa: Wydawnictwo Pedagogiki Akademii Specjalnej.

Radziewicz-Winnicki, A. (2008). Pedagogika społeczna. Warszawa: Wydawnictwa Akademickie i Profesjonalne.

Reykowski, J. (1975). Teoria motywacji a zarzq̨dzanie. Warszawa: Wydawnictwo PWE. Smith, D.D. (2008). Pedagogika specjalna. Podręcznik akademicki t. I. Red. A. Firkowska-Mankiewicz, G. Szumski. Warszawa: WAPS, WN PWN.

Tomaszewski, T. (1978). Praca zawodowa jako centralne pojęcie kształcenia zawodowego. W: S. Kaczor, Z. Wiatrowski (red.), Kształcenie zawodowe w służbie gospodarki i kultury narodowej. Warszawa: Wydawnictwo WSiR.

Zych, A. (2001). Słownik gerontologii społecznej. Warszawa: Wydawnictwo Akademickie Żak. 